\title{
The Dutch Reformed Church is continuously changing: Revision of the church order of 1998
}

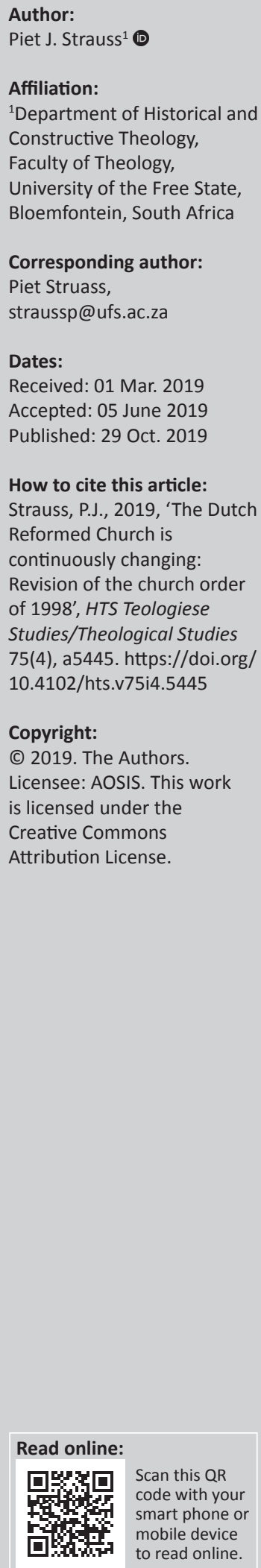

As the name of the title suggests, the Dutch Reformed Church is continuously changing or reforming. This change focuses on improvement as times change. In 1994, the Dutch Reformed Church was confronted with a new South African society built on a new paradigm, as expressed in Chapter 2 of the Constitution of the Republic of South Africa 1996. Against this background, the General Synod of 1998 amended the church order. The amendments, including employment relationships of ministers, church discipline and the relationship between church and state, echoed the new South Africa and were an attempt to operate anew from reformed constants or principles. As a changing church in a changing situation, the Dutch Reformed Church wished to reform on these points or change on the basis of reformed principles.

Keywords: Continuous Reform; Changing Circumstances; Church Order Based on Reformed Principles; Employment Issues; Discipline; Church and State.

\section{Problem statement}

The church, any church, is continuously changing because of the fact that its people constantly choose, develop, stagnate or go downhill and thus change.

The word 'reformed' suggests that churches strive to change continuously and it does not imply change simply for the sake of change. Within the context of the church, this word means change for the sake of improvement, even if the situation does not lend itself thereto. In reformed churches, change by way of reformation is used as a motto: ecclesia reformata semper reformanda. A reformed church is continuously reforming. To quote Koffeman, with his Dutch background: '... de her-vormde kerk dient steeds weer her-vormd te worden' [... the re-formed church still needs to be re-formed] (Koffeman 2009:35). From a biblical viewpoint, a reformed church must continuously grow in its obedience to God. The term 'grow' is appropriate because reformation focuses on continuous or evolutionary improvement, where step 2 implies and grows from step 1 , a formed and healthy growth (Strauss 2010:16). Heyns refers to the reformation of society as he paves the way for both structural reformation and reformation of the individuele en sosiale lewe in strukture of samelewingsverbande [individual and social life in structures or social contexts] (Heyns 1989:71-75). At any rate, true reformation or to be reformed is change for the better.

Post-1994, the Dutch Reformed Church in South Africa was confronted with a new country and a new social paradigm, as formulated in Chapter 2 of the Constitution of the Republic of South Africa, of 1996. This was performed by way of the Bill of Rights and its focus on individual freedoms. Court findings and state laws are subjected to this bill that also gives the protection of the courts in the case of discrimination against people on the basis of the bill (Kleyn \& Viljoen 1999:241-243, 252-253, 259, 270). The Bill of Rights advocates individual freedom, including freedom of religion, freedom of speech and freedom of association. The Constitution with a non-racial, non-sexist, liberal democracy builds on openness, democracy, freedom, equality and human dignity as core values of society (Kleyn \& Viljoen 1999:241-244, 258-261). In 1998, a Study Commission of the General Synod of the Dutch Reformed Church mentioned a omvattende transformasie [comprehensive transformation] of society that must eradicate apartheid and establish the values of the Constitution. In this new society with a new think-and-act climate, the Dutch Reformed Church must proclaim its prophetic voice and promote a value system based on the Bible. According to the Study Commission, this climate causes the withdrawal of members of the Dutch Reformed Church from public life; a new emphasis on the rights of the Afrikaner - a vast majority of the members of the Dutch Reformed Church; members' weaker connection with the Dutch Reformed Church and its tradition; a struggle with its reformed identity; and members' moral and dogmatic uncertainty (NGK 1998:68-78).

Note: The Church in need of Change (agency), sub-edited by Erna Oliver (University of South Africa). 
Under these circumstances, the General Synod of 1998 stands out as the synod that stabilises the core values or reformed character of the Dutch Reformed Church (Strauss 2013:32-58). The outstanding matters of this synod include the Dutch Reformed Church's readmission to full membership of the World Alliance of Reformed Churches and its accepting of this body's 'joint resolution', which was the Dutch Reformed Church's farewell to, or final leave of apartheid's ideology (NGK 1998:412-413); the General Synod's acknowledgement of the Three Forms of Unity as its confessions of faith because they are Biblical in the faith which they formulate and confess - not necessarily in every textual reference or remark regarding non-faith issues (NGK 1998:414-415); the confirmation of every member's call to maintain an 'authentic' Christian lifestyle in the new society, and the Dutch Reformed Church to remain the Church of Christ in South Africa, with all the consequences attached thereto (NGK 1998:416-417).

It is lesser known that this synod would also review the Church Order - DRC CO 1994 with a view to a new Church Order of the Dutch Reformed, namely, Church DRC CO 1998 - and would, in the post-1994 state of affairs, amend it more than what is usually the case with a church order at a General Synod. This review, requested by the General Synod of 1994, would not directly result from the new country and its mark on the Dutch Reformed Church. Rather, in the 4 years up to the reviewed Church Order of the General Synod of 1998, new issues in the country would compel the Dutch Reformed Church to show signs thereof in DRC CO 1998 (NGK 1994:455, 480, 1998:454-463). A new Word-bound church order in a new situation can firmly guide the church through troubled waters. In addition, this stability is possible if it concerns true reformation or an important orientation to scriptural constants or principles for the church order. These issues are simply a 'must' in a reformed church order (Strauss 2010:15-20).

Three new sections in DRC CO 1998 are linked to the new post-1994 South Africa: articles 12-14, the minister serving the congregation or church against the background of new labour laws in South Africa (NGK 1998:340); articles 58-64, church discipline with a view to the newly discovered pastoral-ecclesiastical nature of discipline and discipline of those who, as employees, are paid by the church; and articles 65-67, with a view to a new society and the church's relationship with society and the new state authority (NGKO 1994:4, 13-16, 16-17, cf. NGKO 1998:4-8, 20-25, 26). This article focuses on these three issues that were reviewed and included in DRC CO 1998. Was this a sensible change? Was there talk of reformation?

\section{Reforming DRC CO 1998}

In preparing DRC CO 1962, J.D. Vorster, who may have written the first four chapters of the original DRC CO in 1962 and edited the remaining chapters (Langner 2007:87), mentions it as being Die Dordtse Kerkorde aangepas by die eise van die dag [The Church Order of Dordt or DCO adapted to the demands of the day] (Vorster 1960:13). Vorster's leadership in writing and accepting DRC CO 1962 was acknowledged with his election as the first registrar or actuary of the first General Synod of the Dutch Reformed Church in 1962 (Van der Watt 1973:165). To Vorster, DRC CO 1962's chapter division and thematic content, via Church Order 1959 of the Reformed Churches of The Netherlands (RCN CO 1959, as reflected in Nauta 1971:43-485) based on the Dordt Church Order of 1619 (DCO 1619, a copy of which is found in Pont 1981:176-186), is not surprising - the RCN CO is also a version of the DCO adapted to the demands of the day (Langner 2007:87; NGK 1957:73-74). It is ' $n$ natuurlike vrug, 'n logiese gevolg, 'n sluitsteen, 'n verwagte klimaks [a natural product, a logical consequence, a keystone and an expected climax] in the development of the church order of the Dutch Reformed Church (Vorster 1960:17). Although the successive DRC COs based on DCO 1619 were no longer explicitly pursued later, the pro-Dordt impact has, throughout the years, influenced those who were responsible for the DRCOs, also in 1998. In 1998, the revised DRC CO 1998 would also show traces of DCO 1619.

From DRC CO 1962 to DRC CO 2017, the link with the DCO does not lie in a verbatim or detailed emulation of DCO 1619, but in the chapter division and points of departure or constants of DRC CO for governing the church. In addition, the chapter division addresses the topics of DCO 1619, namely, confession and order of the church, offices, church meetings, the work of the church, church discipline and the church's relationships with the outside world (NGKO 1964:1-16, 2017:1-22; Pont 1981:176-186). In the constants or points of departure, this link is apparent in the Dutch Reformed Church from, among other things, the equivalence of the specific offices, the respect for its own nature as a church, the autonomy and uniformity of church meetings, the official character (under the guidance of the offices) of services, preaching, the administration of sacraments, the spiritual nature of church discipline and its respect for state authority (Strauss 2016:1-12). The DCO 1619 is perpetuated by the adoption of its points of departure for church government which, in the new, changed situation, takes on contemporary forms in a new DRC CO (Strauss 2010:15-17). As a revised church order, the DRC CO 1998 did not wish to scrap its Dordt connection. However, as a typically reformed church order, the DRC CO 1998 wished to adopt a reformed and contemporary character (Strauss 2010:15-20). This was feasible in a liberal democracy with freedom of religion and association.

Under the new circumstances, the changes would also be apparent from an alteration of the broad exposition or composition of DRC CO 1998, with a view to the state of affairs in the Dutch Reformed Church.

In changing DRC CO 1994, the draughtsmen of DRC CO 1998 wanted to narrow down details in the church order that were an additional burden of human provisions, besides the Word of God, for the Dutch Reformed Church. Therefore, the regulation with respect to discipline, dated 1974, was scrapped (NGK 1974:46-58) and Chapter 5 on church discipline was amended. This regulation dates from 
a period of regulation anger and reign in the Dutch Reformed Church. In 1974, because of an apparent lack of specific Dutch Reformed rules for addressing discipline, the General Synod opted for a long, detailed regulation with instructions on church discipline. As the disciplinary bodies of the Dutch Reformed Church easily ignored such details, the latter could thus be transgressed. This regulation made matters difficult for members of the church council who had to take disciplinary action based on the regulation for the correct order or procedure. The civil court could use these errors as one of its standards for reviewing disciplinary cases in the Dutch Reformed Church. The regulation rendered the disciplinary cases clinical and technical without the necessary pastoral and fair mood (Sadler 1979:33-34). In an attempt to exempt church discipline from this detail, the DRC CO 1998 opted for more lasting, general provisions for discipline to be used with love, righteousness and sound judgement. DRC CO 1998 follows DCO 1619 in that church disciplinary cases are cases of a spiritual nature (Pont 1981:184). These pastoral and church-orderly matters based on the Bible must be dealt with reasonably and justly (NGKO 1998:20). ${ }^{1}$ The provisions, including the additional decisions, are considerably shorter than the regulations and inform the synod as to how to approach its task from a pastoral-reasonable perspective. The decisions must equip the Dutch Reformed Church, in a transition period, to reform and implement discipline according to the Bible (NGKO 1998:20-25).

The DRC CO 1998 also communicates explanatory and helpful decisions, as a temporary and transitory measure, in order to highlight its articles as channels for order in the Dutch Reformed Church and to promote the correct handling of DRC CO 1998 (NGKO 1998:3, 5-8, 9-11, 20-23). These decisions depended on a simple majority, whereas an article in the church order depends on a two-third majority of the General Synod for approval (NGKO 1998:16). They were easier to amend, less significant and lasting; they were considered a help in matters concerning church order. With this exposition, DRC CO 1998 wanted to implicitly convey the following to the Dutch Reformed Church: Synods and their commissions must use their discretion to handle the church order in a reformatory manner, that is, with spiritual insight and faith. With its insight into faith, the Dutch Reformed Church must apply DRC CO 1998 and discipline not as an importunity, but as an asset for the development of faith. DRC CO 1998 should not burden the Dutch Reformed Church with unnecessary detail and an obligation to human laws; rather, it should motivate the Dutch Reformed Church to apply order in building the faith of members of congregations. In addition, the DRC CO 1998 should, by implication, maintain joint issues with the DCO 1619 (NGKO 1998:1, 9, 16, 20, 27).

1.Sadler refers to church disciplinary bodies as instances with a quasi-judicial function (1979:25). This common law term implies that, in discilpinary cases, the church is seemingly pre-occupied with juridical actions, although it is, in fact, not a legal entity. In such cases, however, and from the point of view of the court, the church remains bound to the rules of natural justice that ensure justice in all quasi-judicia actions: audi alteram partem and nemo iudex in causa sua [fairness and prope attention]. These rules are based on fairness and according to the principles of Scripture (Coertzen 2003:210; Du Plooy 2007:18; Sadler 1979:51).

\section{Employment relationships}

The amendments to, and additional decisions in DRC CO 1998, articles 7, 8, 9, 12 and 13 (NGKO 1998:3-8) clearly signal the presence of DRC CO 1998 in post-1994 South Africa. In its second report to the General Synod of 1998, its Law Commission informs the synod that the hele diensverhouding [entire employment relationship] of the minister of the gospel should be scrutinised again in light of die nuwe arbeidswetgewing [the new labour legislation]. Some of the aspects in DRC CO 1994 relating to the relationship between the Dutch Reformed Church and the ministers in its service are irreconcilable with this legislation. To uphold the biblical requirements for the church and its offices and to acknowledge the state authority as legislator, the Dutch Reformed Church must re-assess its employment relationship with ministers, and the DRC CO 1998 must more clearly express the issues involved (NGK 1998:340).

Under the new circumstances, the Law Commission calls for a clearer church-orderly assessment regarding the hele diensverhouding [entire employment relationship] of the salaried employees in the Dutch Reformed Church. As the biblical requirements for church and office must be upheld, the new labour legislation (the Labour Relations Act 75 of 1997 and the Basic Services of Employment Act 75 of 1997) affords the Dutch Reformed Church an opportunity to keep issues as church issues, but to formulate these anew under the new circumstances as well as to renew and reform the employment relationships of ministers. These new acts regulate issues pertaining to employment relationships: working hours, leave, the nature of the service, wage, termination of and amendment to the service agreement and legal procedures (NGK 1998:340-342).

To avoid misunderstanding, some of the Church Order Commission's arguments for the amendment to DRC CO 1998 were also put before the General Synod. From a church perspective, the following are the most relevant: (1) the Dutch Reformed Church is not obliged to simply take over state legislation and sacrifice its independence in order to act fairly towards ministers, and (2) when the church acts fairly and equitably, the government or state courts do not have a problem with its own handling of employment relationships. By way of the Constitution of 1996 and from a legal perspective, the state authority is only interested in the fair handling of employees. In addition, major and independent churches are not expected to take over state laws as their own.

Article 7 of the DRC CO 1994 concerns a synod that calls up a minister. Article 7 of the DRC CO 1998 now contains seven provisions or aspects. Basically, the traditional callup letter is an offer of service, of which the final detail is negotiable and included in a service agreement, signed by both the synod and the minister. Besides the synod, a ring or synod is selected as a professional meeting place for ministers in the service of this instance (NGKO 1998:3). A decision in article 7 is about a pro forma professional letter containing essential details of the service agreement and a 
help for synods (NGKO 1998:3). According to DRC CO 1998, article 8, the presbytery controls the actions for calling up a minister. In DRC CO 1998, article 9, on the tasks of the minister - without mentioning any reason the preaching of the gospel, as one of the tasks of the preacher of the gospel (this term is kept in the first sentence of, or introduction to the article), is replaced with die prediking [the preaching].

Article 12 of the DRC CO 1998 on the termination of service of the minister is internally amended by approximately three pages of additional decisions. There are three possible ways of terminating the service: the result of a disciplinary case or a strange church word, misbehaviour, incompetence or unsuitability for the specific position and the financial inability of the congregation or the church to further support the position, with bedryfsvereistes [professional requirements]. These vereistes [requirements] and the expression wangedrag [misbehaviour] reflect the influence of the labour or state legislation concerned. In a moment of neglect, church terms are replaced with profane or non-church labour terms. According to this pro-authority idea among decision-makers or agenda keepers, the Dutch Reformed Church shows that it takes South Africa's new labour legislation seriously. The Dutch Reformed Church only wished to remain a pure church, but it was defiant. Other churches would simply adhere to their own ability to dictate relationships with their employees (Van der Vyver 1972:182-183).

Two factors regarding DRC CO 1998 and the termination of service would point to a pastoral and fair attitude by the Dutch Reformed Church and the General Synod. Firstly, a minister's misbehaviour, incompetence or the financial ineptitude of the church are the final option, if all else fails, for termination of service. Because of the circumstances, the importance and the high profile of preaching the gospel, the church must make room for repentance, forgiveness and reparation, and accept fallible, faithful office-bearers who are renewed by God and his Spirit for service, unless reformation - over a reasonable space of time - does not materialise and the last option was the only way out. Secondly, according to the church's disciplinary body, termination of service indicates that the damage caused is so great that this person can no longer meaningfully pursue his or her preaching, and that individual interest must comply with church interest or the welfare of the organised body of Christ (NGKO 1998:25).

It appears from the additions concerning the elder and the deacon that DRC CO 1998 follows a new course as far as the offices in the Dutch Reformed Church are concerned. An elder must focus on caring for the flock in various ways, but the church board gives specific instructions or responsibilities to an individual elder. This also applies to a deacon who does practical service (NGKO 1998:8-9). This highlights the importance of the local church board doing its work locally and with initiative. This is true reformation.

\section{Reformed discipline}

It has been pointed out that the new Chapter 5 of DRC CO 1998, with its five pages of articles and additional decisions on church control and discipline, replaces DRC CO 1994's three pages of articles and five pages of regulations. To protect the pastoral-canonical nature of discipline in the Dutch Reformed Church, DRC CO 1998 had to ensure that simplified, pastoral and drastic disciplinary enquiries are possible and that the pastoral gathering and leaving actions of transgressors run justifiably based on the motive of love (NGKO 1994:13-16, 68-73, 1998:20-25).

In its introduction on the purpose and procedure of discipline, DRC CO 1998 does not amend the three aims of church discipline, namely, the honour of God, the welfare of the church and the keeping of the sinner.

This line of thought runs via Calvin in the 16th century (Sizoo III sa:260-262) through to DRC CO 1994 (NGKO 1994:13). While the regulations for the procedure of discipline, according to DRC CO 1962 to DRC CO 1994, are found in the gospel, the church order and other provisions of the church (the discipline regulation?), DRC CO 1998, article 58.2, now provides that these regulations also occur in the confessions of faith of the Dutch Reformed Church. Everything points to the fact that, from a reformatory perspective, the General Synod of 1998 made a mistake. There are no regulations for discipline in the confessions of faith, because these writings confess only the scriptural nature and ecclesiastical need for discipline. ${ }^{2}$ Although the General Synod of 1998 wished, with this addition, to show its devotion to the confessions of faith, its ignorance points to a misplaced devotion. The Dutch Reformed Church fathers of 1962 were apparently more au fait with the content of the Three Formularies of Unity than the Dutch Reformed Church's General Synod of 1998 was. In addition, ander bepalinge van die Kerk [other provisions of the Church] traditionally point to the discipline regulation and its rules; this regulation has now been removed. Any additional provisions to the church order complicate discipline in the Dutch Reformed Church and inhibit the reformatory passion of the General Synod of 1998.

DRC CO 1998 amends openbare ergerlike sondes [public offensive sins] (NGKO 1994:14) as sins that are officially included in the agendas of church disciplinary meetings or bodies to sins that lead to openbare aanstoot [public resentment]. The new post-1994 South Africa also strikes when the iron is hot when wangedrag deur werknemers van die Kerk in terme van diensverhoudinge [misbehaviour by employees of the Church in terms of service relationships] also deserves to be disciplined. The following critical question thus arises: is a public resentful sin committed by an employee of the Dutch Reformed Church misbehaviour, according to DRC CO 1998, worthy of disciplinary action? Why exclude this with this insertion? Does this then require a different procedure? DRC CO 1998 is silent on this.

2.See NGB article 29 and HK Sunday 31, NG Kerk-Uitgewers (1982:29, 62-63). 
According to DRC CO 1998, disciplinary sins, as far as church meetings are concerned, clash with the Word of God and the confession of the church. Sins that are known or made public on account of Matthew 18:15-17 and by a formal claim, a leaked rumour or an official report that lands on the table of a disciplinary body, are public offensive sins. Article 61 of DRC CO 1994 (NGKO 1994:13) rules that a transgression of the church order that can also lead to disciplinary action is scrapped. In a reformed church, the transgression of written documents such as church orders sins can only lead to disciplinary action when it concerns a biblical principle or commandment following the transgression of this document, for example, contempt of the church (fifth commandment) after the contempt of the church order. A church order is not the agreement or contract of the church community that protects members' rights and determines the course of the church. This links church rights to basic human rights that drive church management instead of the Bible doing the driving. If the Word determines the spirit and behaviour in the church, any human rights or church order measures are shifted into the background (Strauss 2010:16; Visser 1999:1).

DRC CO 1998 expands on the ways in which an official disciplinary case lands on the table of the synod. This can be a written complaint, a rumour or a report to the church council (normally in written form) deriving from official activities. The latter facilitates the medium of the complaint because a report focuses less on the accuser(s) with the consequences associated therewith. In addition, an official report shows that this is about reasonably weighty, and therefore, offensive matters or sins and not simply a trifle (NGKO 1998:21).

A break with tradition for the Dutch Reformed Church is DRC CO 1998 enabling a church disciplinary body or synod to appoint a plenipotentiary commission to handle a disciplinary case with the power to settle in his stead or on behalf of him. In the case of a church council, such a commission must consist of at least five members - according to a decision in article 61 . Such ruling must be motivated by justice and fairness. The commission must be sufficiently large in order to prevent control by one or two members and thus partiality.

Two elders of the church council must serve on this to maintain the link with the congregation in which the matter occurs and with the congregational nature of church discipline. At least one member must be from the church or from other congregations. The latter can counteract local opinion and avoid unilateralism. The church council can also appoint experts within or outside the congregation to facilitate disciplinary cases and ensure justice, perspective and thoroughness (NGKO 1998:22). Briefly, DRC CO 1998 places official disciplinary investigations into the hands of church experts without having to resort to clinical public court cases. The scaled-down disciplinary body must respect and ensure the pastoral nature of the disciplinary investigation or discussion.
Another break with tradition is DRC CO 1998 article 61.3's provision that the synod or its proxy, upon receipt of the complaint, rumour or report, first determines whether this sin is worthy of disciplinary action or offensive to the public. If this is not the case, it must be dealt with differently. The synod or disciplinary body can, prior to the investigation, attempt to solve the problem by means of pastoral care, reconciliation or the handling thereof as a controversy. Should this initiative fail, the investigation will proceed (NGKO 1998:21). Besides the fact that DRC CO 1998 simplifies the official disciplinary action in the Dutch Reformed Church and maintains its pastoral-ecclesiastical nature, justice and fairness within the church as ' $n$ geloofs- en liefdesgemeenskap [a community of faith and love] (NGKO 1998:20 article 59:1-3) means that disciplinary cases must be addressed with love, patience and seeking the sinner's heart. As with the termination of service of a minister of the gospel or an official, there is room for repentance or reflection, recovery and reconciliation through disciplinary measures that find an answer to the situation of the member and the church concerned.

Referring to the aim of church discipline in HK Sunday 31, Veldkamp (1975) declares:

De zondaar wordt dan niet hardhandig buiten de deur geplaatst, maar de kerk verklaart dat hij zichzelf door zijn onboetvaardigheid buiten de gemeenschap van Christus geplaatst heeft. Maar ook dat is niet het einde van de tucht... Ook deze sleutel (deur God aan die kerk toevertrou) is gemaakt van het goud der liefde ... (die kerk) viert haar hoogste triumph, als zij met deze sleutel de deur voor de berouwvolle zondaar weer mag opendoen. [The sinner is not rudely thrown out the door, but the church declares that he (the sinner), as a result of his impenitence, has put himself outside the community of Christ. This is not simply the end of the discipline... This key (entrusted to the church by God) is made from the gold of love ... (the church) celebrates her highest triumph when she is again allowed to open the door to the remorseful sinner.] (pp. 105-106)

Although DRC CO 1998 treads new reformatory paths with respect to church discipline, the principles of fairness and justice for church discipline as a spiritual action link this discipline to the constants provided by DCO 1619 and discipline. DCO 1619 labels church discipline as spiritual and different from the physical enforcement of punishment by the state. In the church as a community of faith and love, discipline as a pastoral-ecclesiastical action is a natuurlike gevolg [natural result]. In the chapter on church control and discipline, DRC CO 1998 is still based on DCO 1619 or remains the 'Dordtse Kerkorde, aangepas by die eise van die

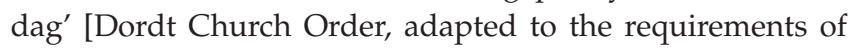
the day] (Strauss 2018:8; Vorster 1960:13).

\section{Church and society and church and state}

In its statements on the Dutch Reformed Church and its relationship with the South African society and the South African state authority, DRC CO 1962, which, according to Vorster (1960), wanted to be the DCO 1619 adapted to the requirements 
of the day, did not adhere to or copy the DCO 1619 adapted to the requirements of the day. On the contrary, DRC CO 1962 articles 65-69 emphasised two aspects. Firstly, it was imbued with premises of the Christian or neo-Calvinist philosophical sociology of the 20th-century Netherlands, with exponents such as Abraham Kuyper and Herman Dooyeweerd. Secondly, it oozed with church sympathy for the South African state authority in the 1960s (Strauss 2018:948-949). With H.F. Verwoerd as Prime Minister at the time, the state led (through apartheid, rebaptised as separate development) the Sharpville crisis in March 1960; South Africa's withdrawal from the British Commonwealth of Nations in 1961, and the birth of the Republic on 31 May 1961. In this process, the state became isolated and was exposed to intense national and international criticism (Kapp \& Gaum 2008:1157-1158). This criticism caused the proapartheid Afrikaner community in the then-governing National Party, of which many of its members were members of the Dutch Reformed Church, to land in the dock. Critics of apartheid referred to the Dutch Reformed Church as the 'National Party at prayer' (Rapport Weekliks 03/02/2019:11).

Truly neo-Calvinist, DCO CO 1962 calls the church selfstandig in eie bevoegdheid [autonomous ability] or soewerein in eie kring [sovereign within its own sphere] (terms borrowed from HG Stoker, Kuyper and Dooyeweerd, Strauss 1993:13). The church participates in the legal relations of the state in exercising its civil rights and accepts the laws of the state in so far as these do not clash with the Bible. Atypical of an efficient, non-emotional reformed church order, DRC CO 1962 declares that it accepts with dankbaarheid [gratitude] the legal protection of the state as well as the state's recognition of its onvervreembare [vested] right to freedom of religion in confession and assembly. During the crises of 1962, the Dutch Reformed Church promised naively and honestly - nobody requested such flattery - not to misuse its freedom by undermining state authority or causing uproar on the level of public law. At this time, such situations were attributed to organisations such as the African National Congress (ANC), the Pan Africanist Congress (PAC) and the South African Communist Party (SACP), for which security laws were accepted in Parliament (Grobler 2012:369-388). The Dutch Reformed Church did not wish to make matters worse for ons regering [our government] that consists of ons [our] members. Yet, DRC CO 1962 considers this a call of the Dutch Reformed Church to address the state authority and the world in an ecclesiastical-prophetic manner. According to DRC CO 1962, the Dutch Reformed Church will, on a positive and Christian basis, cooperate with and support social organisations that fight against social evils and for educational interests.

In a modern differentiated society (another neo-Calvinist term) such as white South Africa, such a church resolution occurs almost naturally and essentially. In 1962, the influential Dutch Reformed Church toesien [ensured] that educating and teaching the jeug [youth] will be Christian in gees en rigting [in spirit and direction]. In fact, the Dutch Reformed Church has the required influence and authority in society. It not only acknowledges the autonomous competence of educational institutions, but also has the right, according to DCO CO
1962, to expect schools and universities to provide Christian education for children and the youth. In addition, the Dutch Reformed Church will take pity on its people and strive for the Protestant-Christian character of the Afrikaner, because it experiences the interests of the Afrikaner. The Dutch Reformed Church acknowledges the existence of associations with a spiritual or faith purpose (NGKO 1964:14-15).

With words such as dankbaarheid [gratitude] and not ondergrawe [undermine], the Dutch Reformed Church, through DRC CO 1962, declares its sympathy with the South African government. Expressions such as selfstandig in eie bevoegdheid [autonomous ability], soewerein in eie kring [sovereign within its own sphere] and moderne gedifferensieerde samelewing [modern differentiated society] reveal the spiritual and academic nature of the Dutch Reformed Church (Strauss 1993:13-15). Similarly, the Dutch Reformed Church would find philosophical-ethical grounds on which to fundamentally build the policy of separate development and support it from a church perspective. The climax in this regard was the General Synod's document of 1966, 'Ras, volk en nasie in die lig van die Skrif' (NGK 1966:86ff.). The influence of Dutch neo-Calvinism also reached a climax in the Dutch Reformed Church in the 1960s (Strauss 1994:203-208).

Against this background, the Dutch Reformed Church found it difficult to maintain DRC CO 1994 in 1998, with its attitude on the Dutch Reformed Church and the society of 1962. The Dutch Reformed Church did not express the same gratitude towards the new government, as this would amount to courting and embarrassment. There was no reason to question the public order of law and the legal protection of the church by this government. In addition, the neo-Calvinist thinking of 1962 could not simply be transferred to the new country. The terminology of DRC CO 1962 was aimed at the Western sector of pre-1994 South Africa. Via DRC CO 1998, the Dutch Reformed Church had to inform its position regarding the new post-1994 South Africa.

In DRC CO 1998, Romans 13 is used, in church terms, for the task of the government, when it implies regsbepaalde beskerming [legal protection] of the Dutch Reformed Church, of all churches. The Dutch Reformed Church can rightly expect this from the state authority, as it is the state's responsibility, with its acknowledged control over the historical physical power of the sword (police and army) towards all in the country. The church can make a request, but the Dutch Reformed Church cannot instruct the government on its specific domain. Just as the Dutch Reformed Church rightly adheres to its freedom of faith or its faith-determined sovereignty within its own circle, thus, the state can rightly maintain its freedom as juridical integrator in the general legal interest of South Africa in its own circle. This neo-Calvinist opinion remains valid!

DRC CO 1998 does not exact freedom of faith for the Dutch Reformed Church only because the Constitution of 1996 makes this possible with its Charter of Human Rights, but also because Christ is the head of its church. Besides that 
DRC CO 2002 also appeals, in terms of the South African Constitution, to its constitutional right of freedom of religion (NGKO 2002:1). The reason for the Dutch Reformed Church's freedom of religion lies in Christ and not in the democratically accepted Constitution. In turn, the latter provides only juridical recognition of freedom of religion (Strauss 2018:3).

A state authority that is ruled by God in his Providence and that is historically and physically in control of the country is legal. God's Providence makes a government legal, not the support of the majority of its citizens. In this instance, the starting point of DRC CO 1998 is theocentric instead of humanistic (NGKO 1998:26). In addition, freedom of religion means that the church, besides its freedom of association, meeting and worship, is free to give public evidence against the state and society. For the Dutch Reformed Church, the Bible remains the standard for its participation in public legal communication and the exercise of civil rights. In terms of its Constitution, the South African government is neutral as far as religion is concerned (cf. Constitution 1996, article 15, in Kleyn \& Viljoen 1999:269). However, the Dutch Reformed Church is guided by the actuality of the Word in any situation or society. In terms of the relationship between the Dutch Reformed Church and free associations and society, DRC CO 1998 adheres to the Word as the standard. The same applies for the Dutch Reformed Church and school and post-school education (NGKO 1998:26). The Church Order of 1990 (NGK 1990:712) dismisses the fact that, at an earlier stage, the Dutch Reformed Church wanted to be a factor in developing the Protestant-Christian character of the Afrikaner people (NGKO 1964:15). As a church of Christ for all, the Dutch Reformed Church cannot, from a reformatory point of view, bind itself to developing a people under the authority of the culture organisations of that people with the exclusion of others (NGKO 1998:26-27).

Although the Charter of Human Rights, with its freedom of religion and association, was applied in South Africa post-1996, the Dutch Reformed Church remains, according to DRC CO 1998, a free church or institution of faith guided by the Word of God. The church also expects the state authority to comply with its legally determined protection of the freedom of the church on the basis of its legal task in society, and to restrain the state from interfering in church matters. In this new era, the Dutch Reformed Church still wants to maintain its church-prophetic calling. Post-1994 South Africa must be reminded of God's Word-bound prescriptions for living. The General Synod of 1998 remains consistent when it claims its freedom as church and encourages its members to exercise ' $n$ outentieke Christelike lewenstyl [an authentic Christian lifestyle] in their constitutionally recognised personal freedom (NGK 1998:68$78,83-87,466)$.

\section{Conclusion}

The Dutch Reformed Church is continuously changing. All its changes - also on the DRC CO - are not always improvements, but they remain the trait of a reformed church to continuously reform - 'ecclesia reformata semper reformanda'. The new post-1994 South Africa has confronted the Dutch Reformed Church with a new society. The society and the state are based on a new paradigm or a society with a new foundation. Under these circumstances, the General Synod of 1998 stands out as the Dutch Reformed Church's Synod of stability - stability of its reformed character with respect to Scripture, confession and church order. Changes and new issues in the Dutch Reformed Church have sought a justified attitude in the Dutch Reformed Church on the authority of the Bible; the scriptural loyalty of its confessions in formulating the reformed faith, and its attitude and critical solidarity towards the new government.

The new DRC CO 1998 bears testimony to renewal and reformation. DRC CO 1998 stands out with its renewal of church order and its own or reformatory handling of the employment relationships of ministers and officials against the background of new labour legislation in South Africa in 1995 and 1997. In addition, DRC CO 1998's articles on church discipline again pave the way for church discipline with a pastoral-canonical element. In the 'new' country, with a totally new constitution, government and composition of its registered citizens, DRC CO 1998 emphasises, from Romans 13 , the complementary nature of the state and the church in their relationship with each other. The Dutch Reformed Church assumes that the state's regsbepaalde beskerming [legal protection] of the freedom of religion of the church is a positive sign - as in DRC CO 1962 - but worded differently. In freedom of religion, DRC CO 1998 makes room for the prophetic-critical voice of the Dutch Reformed Church in the new society and towards the state.

In reviewing DRC CO 1998, the Dutch Reformed Church proposes Word-bound and contemporary regulations as signs of its reformed nature.

\section{Acknowledgement Competing interest}

The author declares that they have no financial or personal relationships which may have inappropriately influenced them in writing this article.

\section{Author contributions}

P.J.S. is the sole author of this research article.

\section{Ethical consideration}

This article followed all ethical standards for carrying out research without direct contact with human or animal subjects.

\section{Funding}

This research received no specific grant from any funding agency in the public, commercial, or not-for-profit sectors. 


\section{Data availability statement}

Data sharing is not applicable to this article as no new data were created or analysed in this study.

\section{Disclaimer}

The views and opinions expressed in this article are those of the author and do not necessarily reflect the official policy or position of any affiliated agency of the author.

\section{References}

Unknown Title, Rapport Weekliks, 03 February, 2019, p. 11.

Coertzen, P., 2003, 'Regsbeskerming in die kerk', in R. Torfs, K. Martens \& L.J. Koffeman (reds.), Recht op recht in de kerk, pp. 199-258, Peeters, Leuven.

Du Plooy, A. le R., 2007, 'Beginsels vir regspraak in die kerk', Die Kerkblad 110(3198), 18-20.

Grobler, J., 2012, 'Swart verset teen apartheid, 1950's-1980's', F. Pretorius (red.) Geskiedenis van Suid-Afrika in voortye en vandag, pp. 369-388, Tafelberg, Kaapstad.

Heyns, J.A., 1989, Teologiese Etiek 2/2, NG Kerkboekhandel 1988, Pretoria.

Kapp, P.H. \& Gaum, F.M., 2008, 'Verwoerd, Hendrik French', F.M. Gaum (red.) Christelike Kernensiklopedie, pp. 1157-1158, Lux Verbi, Wellington.

Kleyn, D. \& Viljoen, F., 1999, Beginnersgids vir regstudente, Juta, Kenwyn.

Koffeman, L.J., 2009, Het goed recht van de kerk, Kok, Kampen.

Langner, D., 2007, Teen die hele wêreld vry - Koot Vorster, segsman of profeet? Griffel, Pretoria.

Nauta, D., 1971, Verklaring van de Kerkorde van de Gereformeerde Kerken in Nederland, Kok, Kampen.

Nederduitse Gereformeerde Kerk (NGKO), 1957, Handelinge Raad van Kerke, s.n., s.I. Nederduitse Gereformeerde Kerk (NGKO), 1966, Handelinge Algemene Sinode, s.n., s.l. Nederduitse Gereformeerde Kerk (NGKO), 1994, Handelinge Algemene Sinode, s.n., s.l. Nederduitse Gereformeerde Kerk (NGKO), 1998, Handelinge Agemene Sinode, s.n., s.l. Nederduitse Gereformeerde Kerk (NGKO), 1964, Kerkorde, N.G. Kerk-Uitgewers, Kaapstad.
Nederduitse Gereformeerde Kerk (NGKO), 1974, Kerkorde, N.G. Kerkboekhandel, Pretoria.

Nederduitse Gereformeerde Kerk (NGKO), 1990, Die Kerkorde, NG Kerkboekhandel 1988, Pretoria.

Nederduitse Gereformeerde Kerk (NGKO), 1994, Die Kerkorde, Hugenote-Uitgewers, Wellington.

Nederduitse Gereformeerde Kerk (NGKO), 1998, Die Kerkorde, Hugenote-Uitgewers, Wellington.

Nederduitse Gereformeerde Kerk (NGKO), 2002, Die Kerkorde, Lux Verbi.BM, Wellington.

Nederduitse Gereformeerde Kerk (NGKO), 2017, Die Kerkorde, s.n., s.I.

NG Kerk-Uitgewers, 1982, Ons glo... Die Drie Formuliere van Eenheid en die Ekumeniese Belydenisse, NG Kerk-Uitgewers, Kaapstad.

Pont, A.D., 1981, Die historiese agtergronde van ons kerklike reg I, HAUM, Pretoria.

Sadler, T.H.N., 1979, Die kerklike tughandeling, N.G. Boekhandel Transvaal, Pretoria.

Sizoo, A., s.a., Calvijn Institutie III, Meinema, Delft.

Strauss, P.J., 1993, Op die tweesprong?, UV, Bloemfontein.

Strauss, P.J., 1994, 'Die Algemene Sinode van 1966 van die Nederduitse Gereformeerde Kerk en apartheid', Studia Historiae Ecclesiasticae XX/2, 195-214.

Strauss, P.J., 2010, Kerk en orde vandag. Met die klem op die NG Kerk, Sunmedia, Bloemfontein.

Strauss, P.J., 2013, 'Kerkwees in die branding. Die Nederduitse Gereformeerde Kerk in algemene sinodale verband 1994-2011', Acta Theologica Supplementum 18, Sunmedia, Bloemfontein.

Strauss, P.J., 2016, 'Die Ned Geref Kerkorde van 1962: die Dordtse Kerkorde aangepas by die eise van die dag?', In die Skriflig 50(1), 2016. https://doi.org/10.4102/ids. v50il/2135

Strauss, P.J., 2018a, 'Kerk en staat in twee kerkordes: 'n ontleding van die die Kerkordes van die Gereformeerde Kerke in Suid-Afrika en die Ned Geref Kerk na 1962', Tydskrif vir Geesteswe-tenskappe 58(4-2), 940-954.

Strauss, P.J. 2018b, 'Kerklike tug pastoral-kerkregtelik van aard en daarom billik en regverdig?', In die Skriflig 50(2) 2018. https://doi.org/104012/ids.5212.2336

Van der Vyver, J.D., 1972, Die juridiese funksie van staat en kerk, Butterworths, Durban.

Van der Watt, P.B., 1973, Die Loedolffsaak en die Ned Geref Kerk 1862-1962, Tafelberg, Kaapstad.

Veldkamp, J., 1975, Zondagskinderen, T. Wever, Franeker.

Visser, J., 1999, Die Kerkorde in praktyk, EFJS, Orkney.

Vorster, J.D., 1960, 'Die kerkorde vir die Ned Geref Kerke: Besware daarteen en betekenis daarvan', NGTT 1960, 12-18. 